This is the accepted manuscript of the article, which has been published in Historical journal of film, radio and television. $2019 \mathrm{vol} \mathrm{39(2),}$ 384-402.

https://doi.org/10.1080/01439685.2018.1544197

Article manuscript for Historical journal of film, radio and television

Jaakko Suominen, Ph.D., Professor of Digital Culture, University of Turku, Finland (jaakko.suominen@utu.fi)

J. Tuomas Harviainen, Ph.D., MBA, Professor of Information Studies and Interactive Media, University of Tampere, Finland (tuomas.harviainen@uta.fi)

\title{
Comics as an Introduction to Media Technology: The Finnish Case - Television and Donald Duck in the 1950s and the early 1960s
}

$<$ Abstract $>$ This article deals with the relationship between television - a new form of media technology in 1950s Finland - and the introduction of the Donald Duck comic book. The article analyses the three most essential imaginary perspectives on the uses of media technology: interactivity, publicity seeking and tinkering with a television. On one hand, the article introduces the various ways in which the comic book represented and introduced the media format to the Finnish public, and on the other hand, how it actively participated in the contemporary public debate on the meanings of television and its use that took place at that time. $</$ Abstract $>$

The small Nordic country of Finland suffered greatly during World War Two. Finland, which had been allied with Nazi Germany, tried to maintain its independence and neutrality after the war despite the pressure of the Soviet Union and aimed to rebuild its damaged infrastructure, while at the same time paying significant reparations to the Soviets. 
However, by the 1950s, the rebuilding process had already progressed and a growth in the standard of living took place. This was also seen in the media sector and new household technologies. The construction boom and the construction of new homes was one reason for the need of a substantial number of new household appliances in Finnish homes. ${ }^{1}$ Likewise, new youth cultural phenomena penetrated Finland, from the USA in particular, with various media and consumer cultural products. ${ }^{2}$ In the Finland of the 1950 s, one experienced, for example, the emergence of television. In addition, a new comic book started to appear on Finnish newsstands, Walt Disney's Donald Duck, which turned out to be one of the most popular and influential publications in Finland.

The publication of Donald Duck began in Finland in 1951-1952 and in only a few years, it became very popular with a circulation exceeding 100,000 copies in 1955 — this in a country with a population of 4.3 million people (1960). ${ }^{3}$ The popularity of the magazine reflected the post-WWII trend in which Finnish children's magazines and comic books were largely replaced by American comics. ${ }^{4}$ Walt Disney’s American material was selected and edited for Nordic countries in Denmark until the early 1960’s by Gutenberghus publishing company (later Egmont) and translated into Finnish in Finland. Since the early 1960's, the Nordic Disney comic books was published weekly, compared to the US monthly pace, therefore little by little also some Nordic cartoonists started to draw some material for the comic books. ${ }^{5}$ The comic stories were usually published two years after their publication in the USA in the other Nordic countries, and in Finland even one additional year later. However, there were also longer timespan in certain cases. The careful and textually innovative translation process has been seen as a very important reason for the magazine’s popularity in Finland. ${ }^{6}$ 
The change in the popularity of youth magazines and comic books in Finland was merely part of a larger international change in consumer culture and in the use of domestic technologies.

To highlight this change, the article combines the histories of popular television and Donald Duck comic books. In this article, we examine how comic books represented media technologies and their use in Finland in the 1950s and the early 1960s. We will focus on the ways in which Donald Duck participated in the public discussion about technology and everyday life and portrayed emerging media technologies - specifically television - the pluses and minuses of which were widely debated in Finland in the late 1950s, when broadcasting began. We will answer the following questions: How did Donald Duck represent the technological change brought about by the introduction of the television? How was it itself a part of the change?

The article focuses mainly on three user-technology potentialities in the popular introductions of television as a media technology that dominated in Donald Duck publications: interactivity, common publicity seeking and tinkering. Through these potentialities, this piece touches upon topics such as gender and age, the use and misuse of technology and the personal autonomy of users as well as representations of the possibilities and the limitations of new technology.

The study's primary data consists of ninety stories and other sources retrieved from volumes of Donald Duck comic books from 1951 to 1965 (30 items 1951-1959 and 60 items 19601965); all of the comic strips, magazine covers and additional stories dealing with television in the 1950s and the early 1960s. Television was one of the most popular technologies represented in Finnish Donald Duck comic books, even though it was obviously not the only one. On many occasions, television was introduced simultaneously with other technological innovations. ${ }^{7}$ The article discusses the contexts in which television and Donald Duck arrived 
in Finland, and then moves on to analysis of the aforementioned potentialities. We also deal with the question how the domestication process of television can also be seen in the early 1960's when the television set was also in Donald Duck more of an everyday object than before. Before we can look at the contexts, however, it is necessary to theoretically examine how comic books connect to technology.

The article primarily contributes to cultural historical studies on media and technology that represent so-called ‘third generation media history’ and focuses more heavily on audiences and user experiences instead of media institutions or programmes. ${ }^{8}$ Scholars such as Lynn Spigel, Cecelia Tichi and others have used various sources such as popular writings, intermedial references, ads and oral histories when studying the cultural and social history of television. However, comic books have been rarely studied in this context. ${ }^{9}$ In addition, this study contributes to cultural appropriation and the domestication of technology studies from the perspective of the introduction and domestication of a new media technology with fictional representations. ${ }^{10}$ In many cases, cultural studies related to the Disney Corporation have focused on the mass cultural and critique of globalism, or the personal history of Walt Disney, however, in this article we will concentrate on the local context of an international and transnational cultural product. ${ }^{11}$ This article continues Donald Duck-related television research that the first author has previously undertaken and published in Finnish. ${ }^{12}$ This subject could also be approached from the point of reception studies, but in this case, it is difficult due to the lack of suitable research material. There are no Donald Duck comic book critiques about technology available, no information about readers' surveys, and so forth. One possible data source would have been letters that readers sent to the comic book editors. There are some correspondence between readers and the editor-in-chief, just recently archived and not used before by other researchers. However, the archived letters in the 1950s consist of only rarely comments on the comic stories but usually are inquiries for wanting 
free issues of the comic book, or compliments of having prizes or free Christmas magazine presents for donation for poor children, or correspondence regarding readers' competitions etc. In the early 1960s there were more comments on the comic stories, but usually they were related to general quality of Donald Duck or they were specific character related questions. Due to these reasons, it is not possible to say much about the reception of the comic books. Almost the only thing that we can certain about is Donald Duck's huge popularity in Finland. In addition, one might be able to collect oral historical data regarding the reception and use of Donald Duck comic books, e.g. using the same method that has been done in Finland regarding the early history of television culture, porn magazines or other forms of pornography consumption, or other forms of media usage, but this would require another study. $^{13}$

\section{Technological novelties, household technologies and Donald Duck in the 1950s}

Television was one of the most essential technological novelties in Finland during the 1950s, although the amount of household TV sets did not boom more extensively until the 1960s. In 1958, when public television licenses, in addition to radio licences, were introduced, 7,757 licences were redeemed. In 1960, there were already 92,524 TV licenses and 822,311 licences in $1966 .{ }^{14}$ The number of licenses is quite realistically equivalent to the amount of the TV sets in Finland, so we can observe quite rapid change in the late 1950's and especially the early 1960’s. In the second half of the 1960s, television had penetrated Finland. In 1966, for example, there were 1384000 households in Finland, 3.35 persons in one in average (https://www.stat.fi/til/tjt/2015/02/tjt_2015_02_2017-03-24_tau_001_fi.html), so more than half of Finnish homes had television then. 
There were already some discussions about national television broadcasting in Finland after WW2, however, as mentioned, public operation did not start before the 1950s. The first experiments with cable networks began in the early 1950s and the first airwave broadcast was produced by the Television Club of the Society of Radio Engineers on the $24^{\text {th }}$ of May 1955. The Foundation for the Advancement of Technology received permission for television broadcasting in 1956, and the Finnish Broadcasting Company (YLE) and Commercial Television (MTV) began broadcasting together experimentally in 1957 and then regularly in the beginning of 1958 under the name, Finland's Television. ${ }^{15}$ Tesvisio (TES-TV), owned first by The Foundation for the Advancement of Technology, broadcasted between1956 and 1965. It operated mainly in Helsinki, Finland's capital and later also covered later two other major cities, Tampere (1957-1964) and Turku (1956-1959). It also sponsored programs and commercials, however, it couldn't compete with YLE and MTV due to its limited coverage. YLE bought TES-TV in 1964 and replaced it with channel two in 1965. That was one change taking place in Finland's television operations in 1965.

Consistent broadcasting started in Finland as a public and commercial service. This sort of combination was unique in comparison to all other Nordic countries that had at first only public broadcasting companies. ${ }^{16}$ Broadcasting in Finland started about twenty years later than in pioneering countries such as Germany, Great Britain and the USA. However, Salmi argues that television had already earlier arrived in Finland as an imaginary technology. Social and cultural forms of television, which consisted of many user practices and public debate, were already established in newspaper articles for example. A television set was not a luxury item in Finland, although its rational usefulness was debated during its initial introduction. One can rarely see this kind of moral debate in Donald Duck, but there are stories where one character makes judgements about the usefulness of machine or tries to limit others' television watching. ${ }^{17}$ We argue here, that Donald Duck also constructed first 
the idea of television as an imaginary technology. Salokangas, who has studied the history of the Finnish Broadcasting Company, notes that Finns became aware of television - or 'distant seeing' in the 1930s, when the pioneering countries had started television broadcasting. At the same time, the first Finnish radio amateurs constructed their own television receivers for intercepting and watching those foreign broadcasts. ${ }^{18}$

Television started to become more common after WW2. At first, its diffusion was slow, then more rapid. In the USA, there were only 5,000-8,000 TV sets in 1946, however, television was soon after marketed as a type of furniture for middle-class households, which also represented some sort of symbolical ideal of luxury. In 1950, there were almost ten million televisions in American households; by the mid-1950s that figure was over thirty million. Income from advertising provided capital for the expansion of the television network, while this new medium for popular media did not cause the problems for the radio industry that were forecasted. On the contrary, radio corporations switched quite effortlessly to the television business, repurposing familiar programme genres. The relationship between the film industry and television was more complicated due to the decrease in cinema audiences as a result of the television boom. The USA then became the first 'television nation' ${ }^{19}$

In another pioneering country, the United Kingdom, the number of TV sets rapidly increased as well. In 1947, there were almost 15,000 television licenses, but by 1951 there were a million licenses, and in 1955, there were 4.5 million combined TV and radio licenses. According to media historian Brian Winston, the diffusion of television occurred in other countries after 1952-1953. For this diffusion, one needed not only viewers but also a television technology industry, broadcasting networks, legislation and programmes. ${ }^{20}$ Kortti argues that the 1950s were the golden age for American television, while television's golden age took place in the UK and in other European countries in the 1960s. ${ }^{21}$ 
Denmark - also the Nordic node for diffusing Donald Duck comic books - led the way in the Nordic countries. The Danish national television channel started in 1951, and there were about 10,000 television receivers in Denmark by the mid-1950s. Sweden started to launch regular television activities from the mid-1950s, when there were about 7,000 television sets in the country. This amount rose rapidly, and in the mid-1960s, practically every Swedish household had a television, which was not the case in Finland. Regular television activities began in Norway in 1960, eight years after a proposal in the Norwegian parliament. Obviously, it should be noted that there were experimentation phases before regular television activities in every country. ${ }^{22}$

It is necessary to consider the previously mentioned international introduction and diffusion context when conducting research on Donald Duck stories (which were produced in the USA and circulated to Nordic countries via Denmark) and television in Finland. Salmi has written about the experience of inevitable technological change, which was connected to the 'change has already happened' -discourse. ${ }^{23}$ This change, the emergence of television, had already occurred in other places, and, as it seemed, Finland had to go along with the change in the 1950s.

\section{Television in the Donald Duck comic book}

The introduction of television and its marketing was visible in several stories in Donald Duck comic books during the 1950s. In addition, cardboard television sets were even delivered to new subscribers of Donald Duck as a Christmas gift in $1955 .^{24}$ The gift foresaw the slow invasion of real television devices, and the campaign took place at almost the same time as public television broadcasting began in Finland. Likewise, in 1960, an extra gift was promised to new subscribers. This time is was 'Donald Duck's colour television', a cardboard television with five 'programme sheets' consisting of Donald Duck pictures that like the 
previous version, created an illusory experience of motion picture, now with colours. ${ }^{25}$ These ‘televisions’ were occasionally given to unfortunate non-subscribers with some other Christmas presents when the publishing company was doing charity work. ${ }^{26}$

The cardboard televisions do not only illustrate the marketing strategies of the comic book, but also the importance of children and youngsters as consumers of technology. Helsti suggests that children were the most enthusiastic viewers of television in the early period. They were also the most likely to visit such households that already owned a television set. ${ }^{27}$ Likewise, children were the main audience of the comic books as one can notice when reading correspondence between editors and readers.

Also in Donald Duck, children were most often described as the most active television viewers. For example, in 1960 there was a story where Donald Duck’s nephews wanted a television set so badly that they invented a play where they acted television viewing without a set. Finally, they were able to persuade their uncle to purchase an expensive TV with the help of an attractive saleswoman, but Donald took the television for his own use because the same beautiful woman was singing on television, and his nephews had to continue their imaginary television play. That was one last long story published in the Finnish Donald Duck portraying the purchase of a TV. ${ }^{28}$

Overall, it is conceivable to examine the conceptions of television produced and commented on by Donald Duck comics in the 1950s and in the early 1960s as part of a mediatechnological signification process, which produced and used television as a mental and material artefact.

Because our research material is rather concise, it is not possible to make wide generalizations about changes in television culture and discourse during the 1950s and the 
early 1960s. It appears, however, that stories published in the early 1950s, underlined experiments with new technology and television’s character as a media technological novelty, while in the early 1960s, television only rarely had this value anymore. Instead, television was portrayed more often as some sort of everyday object that was used for relaxation and entertainment, which nevertheless, might have given impulse for action. The characters of the comic story were watching television and from there received the inspiration or a cause to do something. ${ }^{29}$

Television programmes and programme genres started to receive more public attention in the late 1950s comparing to the focus on the TV set themselves. Likewise, TV's Finnish name was settled on as ‘televisio' and not 'näköradio' (visual-radio), which is what it was called earlier. This change predicated the domestication of television in Finland and other Nordic countries as a technological product and a broadcasting media with certain typical programme genres. The social nature of television became more stable. In addition, due to the fact that comic stories were produced in the USA, it was not relevant to present introductions of the television anymore, as television was already diffused in American households.

Donald Duck's role in introduction of programme genres was even more visible in the early 1960s, when for example representing live sports or news reports, Westerns, quiz shows, talk shows or music programs were typical.

The first mention of television in the Finnish Donald Duck was published in the December 1952 issue. It was a written story, 'The Miracle of Christmas Eve’ with one picture: a typical social situation in which a television was being watched. The story connected the installation and introduction of new technology, the different roles of comic characters as well as an Amero-centric Christmas context. Mickey, Goofy, Minnie, Clarabelle and Dumbo were together and smiling in front of a television receiver. In the story, Mickey had bought 'a 
visual-radio’ for Minnie as a Christmas present. Because Mickey and Goofy had not been able to find a mechanic to connect the television, Goofy tried to install the television himself using the instructions provided by the dealer. At the same time, Dumbo the Elephant watched the progress of the installation.

Goofy then climbed on the roof to install the antenna and everything seemed to work well. At first, there was a white spot on the screen and then Santa Claus appeared in his sleigh loaded with Christmas presents. He seemed to have some problems with slippery conditions, and it looked as if Santa Claus would ask for help from the viewers, especially from Dumbo. The flying elephant, dressed in warm clothes, flew up to help Santa. Soon, the others saw Dumbo on the TV screen. When everybody else was already sleeping, Santa carried a snoozing Dumbo back with some presents. However, the television no longer worked when the gang woke up.

The previous story represents several essential conceptions related to the introduction of television. It deals with the first moments of experiencing a new device and depicts the skills needed for technical installation. Second, the device not only functions as a receiver of public broadcasts, but also as a transmitter and as a two-way private online communication medium. In particular, this bi-directional nature was a theme that was represented and played out in cartoons and comic books. ${ }^{30}$ In the early 1960s, this was no longer present in stories, but was still, it an existing theme in the cover drawings. ${ }^{31}$

Not only television, but also other screens and ray tubes were introduced as gadgets such as radar, which Donald Duck used to monitor his nephews, or that the Three Little Pigs used to observe the Big Bad Wolf. On the other hand, comic strips repeated the Orwellian theme of observing single television viewers. Themes of radar and observation were still common topics in the early 1960 stories. $^{32}$ 
This idea of observation and interaction can also be found in television-related jokes and the reminiscences of Finnish television users of the 1950s. Some viewers imagined that early TV hosts commented exactly on their particular and private actions and outlook. ${ }^{33}$ Even then, viewers were already developing 'parasocial relations' ${ }^{34}$ with television stars.

All of this might reveal that television wasn’t necessary interpreted as a broadcasting medium. Eerikäinen notices that the idea of radio consists of the principle of a broadcasting system, but the idea is not its inevitable consequence and not the only option. ${ }^{35}$ Eerikäinen sees broadcasting as a sign of modernism, which constitutes an organizational form in industrial and urban society. Broadcasting is related to industrial production ideology, and at least mentally, to the dense urban city structure. ${ }^{36}$

In popular media and advertising, the idea of duplex interactivity was not around in the 1950s. Instead, popular media emphasized the idea that television brings the world into households. Saastamoinen points out that this idea of 'world television’ was executed in two ways, either the world came to the spectators' home or the spectator themselves moved to the outside world, to the centre of action. ${ }^{37}$ These two themes were intermixed in the Christmas story of the Donald Duck comic book and in comic strips more generally.

\section{On TV, whatever it takes}

In the 1950s, people expected that television would come direct to Finland as a 'finished technology', with colour broadcasting. Moreover, the media published stories about

international experiments with 3D television, related to 3D cinema, ${ }^{38}$ the finite form that was never realized. Finland started with black-and-white technology, even though technically advanced and future oriented discourse dominated popular media. First colour broadcasting 
took place in Finland in 1968, however, colour televisions did not become common before the 1970s. Comic books made parodies of scientific news and took the idea one step further from colour television. In one early story, the nephews of Mickey, Morty and Ferdie, cheated passers-by with their 3-D television, which actually didn’t have a screen at all. ${ }^{39}$ The television box showed the picture through an open hole. Goofy, for his part, experimented badly with a smell-o-vision, and in another story, purchased a wrist radio and a nose television. ${ }^{40}$ In the early 1960s, these sorts of imaginary experiments were rare, but then sometimes Donald Duck portrayed possibilities with more mobile television viewing. ${ }^{41}$ All of these examples reveal the popular discussion on possible futures of television.

The future of television technology was represented as aiming for complete realism: with clear pictures, authentic sounds and multimodality. In cartoons and comic strips, this search for the real, led to an unwanted conclusion - to domestic disaster. ${ }^{42}$ Bolter and Grusin have argued that a search for an immersive experience has been a key marketing strategy with many media technologies. The newest machine is the one that creates the most authentic experience of reality. It creates a virtual space, which is inseparable from reality. ${ }^{43}$ The experiments of the 1950s, and their representations, commented on, among other things, the race between television and cinema in the creation of the most immersive media experience. This was no longer as obvious in the early 1960s.

As mentioned before, stories, which placed more emphasis on television programmes than technology, became more common in Donald Duck in the late 1950s. The comic book represented radio as a more formal news media but underlined television’s clearly entertaining nature. ${ }^{44}$ However, it seems that this started to change partially in the early 1960 s when one can find some stories where television has the role of live news reporter, in many cases connected to sports but not always. ${ }^{45}$ 
The comic books depicted various genres: cooking shows, quiz and talk shows, as well as music and sports programmes, and the stories underlined the active and interactive elements of television production. In one story, Donald Duck prepares dinner by following instructions and recipes from a television chef but is not content with the result. The final picture shows a television screen where Donald Duck has gone to the television studio and thrown a failed soufflé in the face of the television chef. ${ }^{46}$ As earlier mentioned, in the early 1960s, amongst the most commonly described genres were fictional detective stories and Westerns. ${ }^{47}$

Donald Duck's imaginary palette of television programmes was very similar to early television in Finland in the late 1950s in which Finnish television programmes followed international trends. Television borrowed discussion programmes, quiz shows, sponsored soap operas and sitcoms from the radio. The American film industry started to produce cop shows and Westerns for television, internationally. In addition, news became an integral part of the programme catalogue. ${ }^{48}$ For example, based on oral historical sources, it seems that the Finnish audience essentially watched everything that was broadcasted for the first time. ${ }^{49}$

The main character in the television-related stories in Donald Duck comic books was Donald Duck himself as well as his nephews. In many cases their aim in the 1950s was to gain some publicity at all costs. Television was represented in Donald Duck as a sensationalist media that needed participants for wild quiz shows, tricksters or home filmmakers. ${ }^{50}$ In stories, in many cases drawn by Carl Barks, the Ducks tried to get on television, for example, with talking dogs and cats, or by presenting a skill that involved swimming with an orange on top of raw spaghetti or by introducing a glow-in-the dark camel called Abdul. ${ }^{51}$ This changed in the early 1960s, when being in television or being a celebrity wasn't necessary the most important aspect, although sometimes still visible theme. ${ }^{52}$ 
During the 1950s, television was represented as a media for curiosities and exotica, an emphasis that separated it from radio or cinema. Television combined cinema's visual aspects and radio’s real-time topicality. It also utilized the features of sensationalist journalism, which was humorously underlined in comic books. Thus, the represented television was a result of media convergence. In the early 1960s, the role of exotica started to diminish. Furthermore, comic books represented the actual television set as a concrete artefact situated in specific household conditions. ${ }^{53}$ Duckburgian living rooms typically consisted of a brown television set with some round knobs and a loudspeaker at the bottom. The television set had been placed on top of a table or directly on the floor in comic books, and not on e.g. a bookshelf. There were no significant changes in the outlook of the television in the stories from the early 1950s to the mid-1960s, which reflected well the situation with the TV sets in general.

From the 1950s to the 1970s, there were three basic models of television sets in Finland and other countries: a table model, a floor model and a closet model. ${ }^{54}$ The age of closet models lasted only about ten years, and one cannot find any in Donald Duck comic books. Most likely, there was no need for hiding the television in the USA. In Finland, in the late 1950s, the arrival of television generated public debate by elite and religious communities on television's alleged effects that destroyed the normal rhythms and values of life and the invasion of low-standard mass culture and entertainment. ${ }^{55}$ Therefore, some Finns might have wanted to hide the TV in a closet. Television had already been domesticated in the USA, even though this kind of debate was international. In the USA, there had been discussion about the television's potential as a control and propaganda tool, a breaker of family unity and its seduction of the innocents. The same topics were already discussed in Finland before television's arrival. ${ }^{56}$ And today similar debate is taken place with digital gaming devices. 


\section{Tinkering with television}

The conception of the 'right' or 'wrong' use of the new media technology was connected to the introduction of television and other technologies in Donald Duck comic books. Particularly, misuses of television led to comical effects, which entertained readers. The misuse of televisions meant utilizing the TV device as a work tool, a play or cult object. It might also occur during the tinkering with and the developing of television's capacities - and typically - the consequences for such work were disastrous. Television tinkering was typical theme in the 1950s, but no longer as much in the early 1960s. If somebody worked with a television set then, the experiments were usually successful and connected to repair work. ${ }^{57}$

The technological tinkering represented in Donald Duck was a more masculine practice, just as in television advertisements. According to Saastamoinen, when one wanted to underline the easiness or the aesthetics of television devices in ads, the represented user was a woman. However, when advertisers emphasized the technical qualities and performance of television, the user was not depicted or was a man 'who knows technology by feel'. Saastamoinen continues, remarking that the advertising of Finnish television devices in the 1950s and the 1960s in general was, however, more focused on technical qualities than user-friendliness. ${ }^{58}$

Donald Duck comic books also maintained this above-mentioned gendered division. According to Aslama and Puustinen, Donald Duck's male and female roles appeared to be quite similar all the time: 'Men bubble around, compete, invent and create solutions; women are companions and they cook, shop, and sometimes fret. Whereas for example, Donald Duck himself is a multi-faceted person - nice and mean, honest and occasionally a fraud, coward and sometimes a hero - Duckburgian women tend to be either very nice (Grandma Duck, Daisy) or terribly-dangerous (Magica De Spell)' ${ }^{59}$ In addition to this, the number of female protagonists has remained low in comparison to the main male characters, although their 
nature and behaviour can be changed. For instance, the early Grandma Duck was not only a modest and energetic lady of the house but also an old and snappy archetype of agrarian regression.

Representations of television and technology have in general been gendered. For male viewers, the female relationship to technology has appeared often comical, unprofessional or even dangerous. The danger has emerged because of potential destruction, (mis)use or the crossing of 'sacred' borders between gender roles. On the other hand, women have also been represented in the technological context as objects of male gaze and desire: she has been a seductress who falls in love with the machine or technological male professional and therefore indirectly with the male audience. This can be seen particularly in advertising and other popular imagery. ${ }^{60}$ In Donald Duck comic books, this relation between technology and heteronormative seduction and romance is not that essential, although it is still observable. ${ }^{61}$

Daisy and Grandma Duck in particular, and in certain cases Minnie and Clarabelle, rub shoulders with technology in Donald Duck comic books in the 1950s. The telephone was the most typical technological device used by female characters, although Daisy, for example, drives a car or is in the car with Donald. And even though Grandma Duck’s farm differs from urban environments, it is still a production site that needs technologies, such as cars and agricultural machinery. Otherwise, the machines used by female characters are often related to communication, the household or gardening.

Misusers of technology are typically different from the adult male protagonists: women, children, the elderly, primitives, simple-minders or wilder animals. In one Donald Duck story, Grandma Duck does not understand television's novelty value and says that it only shows living pictures - cinema. ${ }^{62}$ With this phrase, Grandma Duck crystallizes Marshall 
McLuhan's notion that old media is the content of new media. ${ }^{63}$ Grandma Duck’s huff is also an example of the wider debate on the relationship between television and cinema.

In another story, unnecessary consumer products and technologies, won from a competition, are put to serious agrarian-production use at Grandma Duck’s farm. This demonstrates Grandma Duck’s role as a technical innovator, which was exceptional amongst the female protagonists of the Donald Duck comic books of the 1950s. One can churn butter with a television tube, further its chassis also became a great artificial mother for chicks when one adds an oil lamp to it. The antenna is remade as a rack for balls of wool. The freezer coffin becomes a great box for wood, a bathtub changes into a drinking basin, floor lamps become bird baths and a pig can loll around in an easy chair so that it does not have to lie on the piggery's messy floor. ${ }^{64}$ Syrjämaa notes that on the one hand, urban electrified homes and country homes were already set at odds against each other in Donald Duck comic strips in the 1930s and the 1940 s. ${ }^{65}$ On the other hand, as we mentioned above, the farm in particular, was a production site where technological aids were necessities. Those tools were particularly related to work and not to entertainment, hobbies or leisure. A new urban technological consuming ethos challenged the agrarian technological production ethos, which sought benefit and rationality.

A similar search for new ways to use technology is already seen - for practicality's sake - in a story in which Mickey and Goofy visit a distant primitive place. In Mickey’s opinion, the native use of the inventions of western civilization is backwards or absurd: an alarm clock is banded to a foot, a gramophone is used as a carousel, a refrigerator has become a shelter from rain and a television a mirror as there is no electricity. ${ }^{66}$ These natives are 'the tropical other', the comical counterpart to urban and modern lifestyles, but when compared to agrarian technological and 'rational otherness', the consumption of technology becomes more playful. 
The encounter is not only connected to the primitiveness of the other but also shows a more general absurdity in technological transfer. Western technological systems cannot be transferred only by exporting end-products as such.

However, Grandma Duck and other non-average users were not represented as only ridiculous or infantile twisters of technology. They might have criticized and overestimated dominant technological expectations and thus mediated this critique to the readers. They opened new and innovative perspectives on technology design, use and representations. By applying Lévi-Strauss’s concept to this framework, misusers were mostly ‘bricoleurs', experimental and creative inventors and innovators who could mix, combine and change material and immaterial substance and the tools of their own environment. They were able to create new material results or interpretations for technology and its use ${ }^{67}$ Such actions and practices are typical in the use, design and signifying of technology. Thus, encounters with technology in Donald Duck comic books can be read as praise for popular and everyday inventiveness and innovativeness. However, comics do not represent the invention process as a whole but increasingly as imaginative novelties that come to life by themselves without major explanations for their functioning. ${ }^{68}$

Although inventiveness is crystallized, specifically in the character of Gyro Gearloose,and some other characters such as Goofy’s young relative Gilbert, Professor Ludwig Von Drake from the early 1960s, as well as with bearded scientist archetypes wearing white laboratory jackets, none of these characters owns a monopoly of invention. There is a more general atmosphere of technological innovativeness in Donald Duck comic books in the 1950s and the early 1960s. Donald Duck himself, his nephews, Goofy, Mickey’s nephews, the Big Bad Wolf and the Three Little Pigs, especially Grandma Duck, Gus Goose and other characters 
(such as Chip n' Dale, who tended to use giant human artefacts for their own purposes) undertake repeated technological experiments.

Duckburgian innovativeness is characterized by the ease of invention, play and imagination. Moreover, it is characterized by the unpredictability of consequences, which readers have come to expect. It is well known that technology often does not behave as it should, especially not in fiction.

\section{Conclusion}

During the late 1950s, the Donald Duck magazine comprehensively introduced new media technology to Finnish households, which then began to purchase TV-sets. However, television was not totally new in Finland as it had already been present, at least as an imaginary media: Finnish people already knew how to use a television before they bought their own TV sets, because they had followed the international discussions about the negative and positive effects of television since the 1940s at least. In the early 1960s, Donald Duck portrayed more domesticated television but sometimes tended to introduce some new developments, such as a new program genre or a mobile use of technology that gave added value for television.

Secondly, television as for example introduced in Donald Duck, was not self-evidently a monolithic mass media or a fixed broadcasting media. Instead, it resembled the media characterizations of the 1990s and the 2000s. The relationship between user(s) or viewers and television varied. The represented relationship was personal, although it contained basic clichés and parodies about television broadcasting, particularly in the late 1950s. For many comic characters, television provided possibilities for active use or even for creative reinterpretations or technological innovation and development. It was not passive viewing. 
Several characters constructed television sets for monitoring their friends or enemies, others tried to improve the technology and create more immersive media experiences. Some protagonists used TV-sets just for fun and some, such as Grandma Duck, did not use them the conventional way, rather they adjusted the TV-set to do something they really needed. Some tried to become television celebrities and some experimented with peer-to-peer communication via the TV.

The fiftieth-year anniversary book of Finnish Donald Duck illustrated the comic books' role as a visionary introducer of science and technology: 'Gyro the Gearloose saw at least half a century ahead in the 1950s, because cooperative worms who catch fish [invented by him in one story] are like future robots' ${ }^{69}$ Similar arguments have been made about the relationship of popular and science fiction with techno-scientific development. ${ }^{70}$ However, it is not essential to think about whether or not Donald Duck comic books were 'ahead their time' as an illustrator of everyday technology from the Finnish perspective. Donald Duck comic books have been part of the technological culture and discourses of their own time. They have been a fragment of the reference network of imaginaries, conceptions, meanings and material objects. Donald Duck comics showed Finns how television belonged in every household and everyday life with all of its curiosities and exceptions.

The Duckburg of the 1950s and the early 1960s is still present in the various layers of technological relations. Firstly, classic Donald Duck comic books, still hugely popular in Finland, are republished frequently. Secondly, even though contemporary Donald Duck production has appropriated current technological novelties, such as mobile phones, computers and the Internet, their imagery and stories, as well as representations and narrative conventions, follow familiar patterns. Those stories continue to show that technological innovation and usage are multi-sided, but technology often has unexpected consequences. 
Third, many technological artefacts look almost the same today as they did some fifty years ago. Comical cars, television sets, robots and so forth have become clichés and a pattern; they are similar, recognizable and preserving elements such as the characters (Donald Duck and Mickey Mouse) themselves. As the writer Hannu Raittila notes: 'Contrary to Finnish village centres, nothing changes in Duckburg - cars, clothes or architecture' ${ }^{71}$

According to Anu Kantola, the contemporary power of Donald Duck is nostalgia - an emotional yearning for the past, for the eternal loop of small town life, 'where every day seems to change everything, but where nothing ever changes'. ${ }^{72}$ That yearning does not only reflect the past but also the future. ${ }^{73}$ This occurred particularly in the 1950s, when Donald Duck told the Finns that technological modernity, which was possible to achieve, would again and again remain beyond our grasp, like a mirage, forever unattainable.

\section{Acknowledgements}

This article is partially based on the first author's earlier Finnish study on Donald Duck in Finland in the 1950s, but this article focuses on television, the timespan covers also the early 1960s, and the dataset is three times larger than in the earlier one (Suominen, Jaakko (2004): "Koneita Ankkalinnassa. Aku Ankka -lehti teknologian kertojana 1950-luvun Suomessa." [Machines in Duckburg. Donald Duck Comic Books and the Cultural Construction of Technology in Finland in the 1950s] In Koti - Kaiho, paikka, muutos. Toim. Päivi Granö, Jaakko Suominen ja Outi Tuomi-Nikula. Kulttuurituotannon ja maisemantutkimuksen laitoksen julkaisuja 4. Turun yliopisto, Pori, pp. 151-188.)

We are grateful to the Academy of Finland for funding the Centre of Excellence in Game Culture Studies project (decision \#312396).

\section{Disclosure statement}


No potential conflict of interest was reported by the authors. 


\section{Notes}

${ }^{1}$ Mika Pantzar, Tulevaisuuden koti: Arjen tarpeita keksimässä [The Future home: inventing everyday needs] (Helsinki: Otava, 2000), 140141; Jukka Kortti, Näköradiosta digiboksiin: Suomalaisen television sosiokulttuurinen historia [From visual radio to the digital box: a sociocultural history of Finnish television] (Helsinki: Gaudeamus, 2007), 36.

${ }^{2}$ Visa Heinonen, Jukka Kortti, Mika Pantzar, How Lifestyle Products Became Rooted in the Finnish Consumer Market. Domestication of Jeans, Chewing Gum, Sunglasses and Cigarettes, Kuluttajatutkimuskeskus Consumer Research Society Centre. Working Papers 80:2003 $<$ http://www.kuluttajatutkimuskeskus.fi/docs/pdf/80_2003_workingpapers_lifestyle.pdf>. Helsinki: Consumer Research Society Centre, 2003).

${ }^{3}$ Juhani Tolvanen, 'Aku Ankan menestystarinan juuret - eli alkoiko kaikki todellakin hiirestä' [Roots of the Donald Duck Success Story Or, did everything really start from a mouse?], Maailman hauskin kuvasarjalehti. Aku Ankka -lehti 50 vuotta. Toim. Juhani Tolvanen. (Helsinki: Helsinki Media, 2001), 27-29. There had also already been preparations for starting the publication in the late 1940s but it had not been possible due to printing technological reasons as well as because the use of paper was still rationed then. In the year 1968, Donald Duck's circulation was 221,665 copies and in the year 1972, there were already 304,654 copies in circulation.

${ }^{4}$ Pirkko Leino-Kaukiainen, ‘Aikakauslehdistön ilmestymisvuodet 1918-1955’ [Finnish magazines 1918-1955], Suomen lehdistön historia 10. Aikakauslehdistön kehityslinjat (Kuopio: Kustannuskiila, 1992), 228.

${ }^{5}$ Tolvanen, 'Aku Ankan menestystarinan juuret'; Timo Ronkainen, 'Ankkari lähestyy murkkuikää' [Donald Duck is approaching teenage], In Aku Ankka. Näköispainos vuosikerrasta 1963, II osa (Helsinki: Sanoma Magazines Finland), i-ii. On translation of Donald Duck in general, see Pia Toivonen, En serietidning på fyra språk (Vaasa: University of Vaasa, 2001).

${ }^{6}$ Tolvanen, 'Aku Ankan menestystarinan juuret'; Juhani Tolvanen, ’Neljä walttiässää eli Aku Ankan päätoimittajat kautta aikojen', In Maailman hauskin kuvasarjalehti. Aku Ankka -lehti 50 vuotta, edited by J. Tolvanen (Helsinki: Helsinki Media, 2001), 114-117.

${ }^{7}$ Author 1.

${ }^{8}$ Jukka Kortti \& Tuuli Anna Mähönen, 'Reminiscing Television. Media Ethnography, Oral History and Finnish Third Generation Media History', European Journal of Communication, Vol 24(1): 49-67.

${ }^{9}$ Lyn Spigel, Make room for TV. Television and the family ideal in postwar America (Chicago: University of Chicago Press); Cecelia Tichi, Electronic Hearth. Creating an American Television Culture (New York: Oxford University Press, 1992). On technology in comic books, see g.g. van Lente, Dick (2004) “Comic Strips as a source for popular images of science and technology: the case of Marten Toonder's "Tom Poes", 1941-1986." Tagung der Gesselschaft fur Technikgeschichte, Wenen - d.d. 12-06-2004; Godhe, Michael \& Frykman, Elin (2000) “Tintin, tekniken och politiken” [Tintin, technology and politics], Tvärsnitt 4/2000, 2-19; Taina Syrjämaa 'Kuluttajan arkea sarjakuvaruuduissa. Aku Ankka 1930- ja 1940-lukujen Amerikassa' [Everyday life of a consumer in comics: Donald Duck in America in the 1930s and the 1940s], In Arjen muisti ja unohdus. Jokapäiväinen elämä historian valoissa ja varjoissa. Turun yliopisto, Yleinen historia. Historian laitoksen julkaisuja n:o 53 (Turku: Turun yliopisto, 1999).

${ }^{10}$ Mikael Hård and Andrew Jamison. 2005. Hubris and Hybrids. A Cultural History of Technology and Science (New York: Routledge, 2005); Mika Pantzar, Kuinka teknologia kesytetään. Kulutuksen tieteestä kulutuksen taiteeseen [How to tame technology: from science of consumption to arts of consumption] (Helsinki: Hanki ja jää, 1996), 73-77. On domestication theories related to media and technology, see also e.g. Roger Silverstone, Television and Everyday Life (London and New York: Routledge 1994); Merete Lie and Knut H. Sorensen (Eds.), Making Technology our own? Domesticating Technology into Everyday Life (Oslo: Scandinavian University Press 1996); David Morley, David, 'What's 'Home' Got to Do with It? Contradictory Dynamics in the Domestication of Technology and the Dislocation of Domesticity', European Journal of Cultural Studies, November 2003, vol. 6, no. 4, 435-458; Roger Silverstone, 'Domesticating domestication. Reflections on the life of a concept', In Domestication of media and technology. Berker, Thomas - Hartmann, Maren Punie, Yves (Eds.) (Maidenhead: Open University Press 2006), 229-248; Leslie Haddon, 'Roger Silverstone’s Legacies: Domestication’, New Media and Society, 9 2007, 16-24.

${ }^{11}$ Schaffer, Scott: ”Disney and the Imagineering of Histories”, Postmodern Culture - Volume 6, Number 3, May 1996; Amy M. Davis, 'The 'Dark Prince' and Dream Women: Walt Disney and Mid-Twentieth Century American Feminism', Historical Journal of Film, Radio and Television Vol. 25, No. 2 June 2005, pp. 213-230. On Disney critics, see e.g. Shortsleeve, Kevin: 'The Wonderful World of the Depression: Disney, Despotism, and the 1930s. Or, Why Disney Scares Us', The Lion and the Unicorn - Volume 28, Number 1, January 2004, 1-30. On earlier Marxists Disney critics, see Ariel Dorfman \& Armand Mattelart, Kuinka Aku Ankkaa luetaan. Imperialistinen ideologia Disneyn sarjakuvissa [How to Read Donald Duck. Imperialist Ideology in Disney Comic Books]. Finnish Translation Markku Koski (Helsinki: Love kirjat, $1980(1971,1975))$.

${ }^{12}$ Suominen, Jaakko: “Koneita Ankkalinnassa. Aku Ankka -lehti teknologian kertojana 1950-luvun Suomessa.” [Machines in Duckburg. Donald Duck Comic Books and the Cultural Construction of Technology in Finland in the 1950s] In Koti - Kaiho, paikka, muutos. Päivi Granö, Jaakko Suominen and Outi Tuomi-Nikula (Eds.). Kulttuurituotannon ja maisemantutkimuksen laitoksen julkaisuja 4. (Pori: University of Turku 2004), 151-188.

maailman välillä - Don Rosan Disney-sarjakuvatpostmodernina fantasiana (Jyväskylä: Jyväskylän yliopisto, 2014); Essi Turvala, “Tähän rivitaloon tulee melkein kaikille Aku Ankka.” Aku Ankka -lehden fanius 1960- ja 1970-lukujen Suomessa (MA dissertation in History, Tampere: Tampereen yliopisto, 2017).

${ }^{13}$ Hilkka Helsti, Kulttuurin muutos ja televisio. Television ensimmäiset vuosikymmenet suomalaisten kokemina (Helsinki: Yleisradio,1988); Kortti \& Mähönen, 'Reminiscing Television'; Susanna Paasonen, Katariina Kyrölä, Kaarina Nikunen \& Laura Saarenmaa, “'We hid porn magazines in the nearby woods': Memory-work and pornography consumption in Finland', Sexualities 2015, Vol. 18(4) 394-412; Jaakko Suominen, ‘Mediasta kysymässä. Radiota, televisiota, puhelinta ja tietokonetta käsittelevät keruukutsut aineistona' [Asking about media. Research invitations on radio, television, telephone and computer as research material] In Tekstien rajoilla. Edited by Sami Lakomäki, Pauliina Latvala \& Kirsi Laurén (Helsinki: SKS, 2011), 233-258.

${ }^{14}$ Raimo Salokangas, Aikansa oloinen. Yleisradion historia 1926-1996 (Helsinki: Yleisradio, 1996); Kortti, Näköradiosta digiboksiin, 70.

${ }^{15}$ See e.g. Salmi, 'Atoomipommilla kuuhun!' Tekniikan mentaalihistoriaa (Helsinki: Edita, 1996); Salokangas, Aikansa oloinen; Kortti, Näköradiosta digiboksiin, 64-74, 90-112.

${ }^{16}$ Jukka Kortti, Mediahistoria. Viestinnän merkityksiä ja muodonmuutoksia puheesta bitteihin (Helsinki: SKS 2016), 243.

${ }^{17}$ E.g. $D D$ 50/1961, 747-758; DD 10/1963, 321-325; DD 19/1964, 598-602; DD 28/1964, 55-58; DD 42/1964, 500-503. 
${ }^{18}$ Salokangas, Aikansa oloinen.
${ }^{19}$ See e.g. Asa Briggs and Peter Burke, A Social History of the Media: From Gutenberg to the Internet (Cambridge: Polity Press, 2002), 236-237; Veijo Hietala, Ruudun hurma. Johdatus tv-kulttuuriin (Helsinki: YLE opetuspalvelut, 1996); Spigel 1992; Brian Winston, Media Technology and Society. A History: From the telegraph to the Internet (London: Routledge, 1998), 122-125.

${ }^{20}$ Briggs \& Burke 2002, 236-237; Winston, Media Technology and Society, 122-125.

${ }^{21}$ Kortti, Mediahistoria, 242-243.

${ }^{22}$ Eli Noam, Television in Europe (New York: Oxford University Press, 1991); Kalevi Piha,'YYrityselämän rooli television tulossa Suomeen', Lähikuva 1995(4), 66; Karl Hugo Wirén, Kampen om TV. Svensk TV politik 1946-66 (Malmö: Gidlunds, 1986).

${ }^{23}$ Hannu Salmi, 'Muutoksen mielikuva ja aikalaiskokemus', In Dialogus. Historian taito, edited by M. Heinonen, L. Koivunen, S. Ollitervo, H. Paalumäki, H. Salmi, and J. Tunturi (Turku: Kirja Aurora, 2002), 403-404.

${ }^{24}$ Donald Duck (DD) 11/1955, 527; DD 12/1955, 562. These page numbers refer to republished facsimile Donald Duck comic books.

${ }^{25}$ DD 25/1960, back cover. See also https://www.antikvaari.fi/naytatuote.asp?id=1216073.

${ }^{26}$ Editor-in-chief's correspondence with readers. Päivälehti archive.

${ }^{27}$ Helsti, Kulttuurin muutos ja televisio, 52.

${ }^{28} \mathrm{DD} 11 / 1960,331-341$. However, there were some mentions of obtaining television later on, like $D D$ 11/1961, 331-338 where purchase of luxury television model was a sign of wealth. On children watching television, see e.g. DD 11/1961, 331-338; DD 50/1961; DD 21/1964, 661-669; DD 28/1964, 55-58.

${ }^{29}$ DD 25/1961, 778-790; DD 26/1961 (1959), 810-818; DD 45/1962, 586-589; DD 37/1963, 346-353; DD 38/1963, 372-377; DD 48/1964, 683-690; DD 17/1965, 522-527; DD 21/1965, 666-669; DD 29/1965 (1963), 86-89; DD 35/1965 (1963), 267-276; DD 52/1965 (1964), 832-839.

${ }^{30}$ See also $D D$ 2/1954, cover.

${ }^{31}$ DD 26/1960, cover; DD 46/1962, back cover; DD 3/1963, cover; DD 22/1964, back cover; DD 30/1964, back cover; DD 2/1965, cover; DD 47/1965, cover.

${ }^{32}$ DD 3/1953, 115-124; DD 3B/1954, 162-165; DD 12A/1957, 726-731; DD 15/1959, 472-475; DD 41/1962, 458-466; DD 27/1963, 3338; DD 3/1964, 84-89; DD 14/1964, 426-438; DD 1/1965, 21-24.

${ }^{33}$ Helsti, Kulttuurin muutos ja televisio, 32-34.

${ }^{34}$ Pekka Isotalus, 'Valmius ihastua tietokonepersoonaan', In Digirakkaus, edited by U. Paunonen and J. Suominen (Pori: Turun yliopisto 2004), 87-96. On Donald Duck's parasocial relationship with a television persona, see e.g. DD 11/1960, 331-341.

${ }^{35}$ Hannu Eerikäinen, 'Broadcasting-järjestelmä, mediateknologian muutos ja vastatelevision utopia, osa 1', Lähikuva 1/1992, 21. See also Spigel, Make Room for TV, 30.

${ }^{36}$ Eerikäinen, 'osa 1', 19-23. See also Hannu Eerikäinen, 'Broadcasting-järjestelmä, mediateknologian muutos ja vastatelevision utopia, osa 2', Lähikuva 2/1992, 36-50., 36-50. On the failures of picture phone development in the USA, see Kenneth Lipartito, 'Picturephone and the information age: The social meaning of failure', Technology and Culture 44(1) 2003: 63-66. In the USA, there were experiments in television monitoring and surveillance in banks and factories as well as with holding presentations in hospitals and schools.(Piha, 'Yrityselämän rooli television tulossa Suomeen', 69.) Similar ideas of interactivity have re-emerged in the renewing of television technology today.

${ }^{37}$ Mika Saastamoinen, 'Mainonta television kesyttäjänä 1950-1960 -lukujen Suomessa', Tekniikan Waiheita 21(4) $2003:$ 32-33.

${ }^{38}$ Salmi, 'Atoomipommilla kuuhun!', 160; Salmi, 'Muutoksen mielikuva ja aikalaiskokemus', $403-404$.

${ }^{39} \mathrm{DD} 12 \mathrm{C} / 1954$.

${ }^{40} \mathrm{DD}$ 3/1955, 125; DD 14/1959, 448-451.

${ }^{41} \mathrm{DD}$ 19/1964, 598-602.

42 See e.g. $D D$ 2/1955, 82 (where Pluto tries to attack a cat on the TV screen and breaks it); DD 8B/1957 (where a pet seal breaks the screen when he sees another seal); DD 22/1959, 704-709 (where Pluto falls in love with another dog on the screen).

${ }^{43}$ Jay David Bolter \& Richard Grusin, Remediation. Understanding New Media. Fourth Printing (Massachusetts, London, England: MIT Press, 2001).

${ }^{44}$ On radio in Donald Duck, see e.g. DD 8B/1953, 354; DD 24B/1958, 794; DD 21/1959, 664; DD 24/1959, 772. Contemporaries in Finland and other countries, however, talked how radio became an entertainment media. See e.g. Briggs and Burke, A Social History of the Media, 236; Paavo Oinonen, Pitkä matka on Tippavaaraan... Suomalaisuuden tulkinta ja Yleisradion toimintaperiaatteet radiosarjoissa Työmiehen perhe, Kalle-Kustaa Korkin seikkailuja ja Kankkulan kaivolla 1945-1964 (Helsinki: Suomalaisen Kirjallisuuden Seura, 2004). ${ }^{45}$ DD 11/1960, 331-341; DD 26/1960, 831-838; DD 21/1961, (1959), 650-654; DD 26/1961 (1959), 810-818; DD 37/1961 (1959), 330335; DD 22/1962 (1960), 682-689; DD 6/1964 (1962), 181-185; DD 25/1964 (1962), 797-801; DD 35/1965 (1963), 267-276; DD 36/1965 (1964), 298-305

${ }^{46} \mathrm{DD} 2 / 1955,110$

${ }^{47}$ On Westerns, see e.g. $D D$ 11/1961, 331-338; DD 50/1961 (1958), 747-758; DD 28/1964, 55-58; DD 52/1964, 834-838; DD 6/1965 (1963), 196-199. On detective stories, see e.g. DD 38/1963 (1961), 362-371; DD 28/1964, 55-58.

${ }^{48}$ See e.g. Hietala, Ruudun hurma, 23-26.

${ }^{49}$ Kortti, Näköradiosta digiboksiin, 112-114.

${ }^{50} \mathrm{DD}$ 19/1959, 605-610 (Scrooge); DD 1A/1957, 10-19.

${ }^{51}$ DD 6/1955, 275-284; DD 23/1958, 714-722; DD 12/1955, 563-572; see also DD 4B/1957, $244-254$ (where Goofy was made into a fashion king).

${ }^{52}$ DD 25/1963 (1960), 801-807; DD 25/1964 (1962), 797-801; DD 47/1964 (1963), 650-659.

${ }^{53}$ See also Juha Herkman, Audiovisuaalinen mediakulttuuri (Tampere: Vastapaino, 2001), 55; Kortti, Näköradiosta digiboksiin, 92.

${ }^{54}$ Maija Mäkikalli, 'Esillä ja piilossa. Radion ja television läsnäolon strategioita 1950- ja 1960-lukunen suomalaiskodeissa', Tekniikan Waiheita 21(4) 2003: 45-56.

${ }^{55}$ According to Hilkka Helsti, opposition against television decreased quite rapidly. In the early period, white collar labourers, teachers, merchandisers, wealthy farmers or other highly-educated people were the first to purchase television sets. For them, the TV set was a modern status symbol that marked their position, progress and high education (Helsti, Kulttuurin muutos ja televisio).

${ }^{56}$ Spigel, Make Room for TV, 45-72; see also Salmi, 'Atoomipommilla kuuhun!', 162.

${ }^{57}$ E.g. DD 19/1964 (1962), 598-602; DD 52/1964, 834-838; DD 6/1965 (1963), 196-199.

58 Saastamoinen, 'Mainonta television kesyttäjänä', 38-40.

${ }^{59}$ Minna Aslama \& Liina Puustinen Aslama, 'Ankkalinnan ihanat naiset.' In Maailman hauskin kuvasarjalehti. Aku Ankka -lehti 50 vuotta, edited by J. Tolvanen (Helsinki: Helsinki Media, 2001), 178-179.

${ }^{60}$ See e.g. Julie Wosk, Women and the Machine. Representations from the Spinning Wheel to the Electronic Age (Baltimore: Johns Hopkins University Press, 2001). 
${ }^{61}$ E.g. $D D$ 11/1960, 331-341.

${ }^{62} \mathrm{DD}$ 12C/1956, 839.

${ }^{63}$ Marshall McLuhan, Understanding Media. The Extensions of Man, Ninth Printing (Orig. 1964) (Cambridge, MA: MIT Press, 2001$)$, 7-9.

${ }^{64} \mathrm{DD}$ 8/1954, 424-425.

${ }^{65}$ Syrjämaa, 'Kuluttajan arkea sarjakuvaruudussa', 36.

${ }^{66} \mathrm{DD} 11 \mathrm{~B} / 1955$

${ }^{67}$ Claude Lévi-Strauss, The savage mind (Chicago: University of Chicago Press, 1966), 17-33. See also Author1.

${ }^{68}$ Dorfman \& Mattelart, Kuinka Aku Ankkaa luetaan, 102.

${ }^{69}$ Risto Varteva, 'Keksiminen on kivaa', In Maailman hauskin kuvasarjalehti. Aku Ankka -lehti 50 vuotta, edited by J. Tolvanen (Helsinki: Helsinki Media, 2001), 56.

${ }^{70}$ David G. Stork (Ed.), HAL's Legacy. 2001's Computer as Dream and Reality (Cambridge, MA: The MIT Press, 1997). Cf. Thomas Haigh, 'Technology's Other Storytellers: Science Fiction as History of Technology', In Science Fiction and Computing. Essays on Interlinked Domains, edited by D. L. Ferro and E. G. Swedin (Jefferson: McFarland, 2011), 13-37.

${ }^{71}$ Hannu Raittila, 'Uusi Jerusalem - Ankkalinna kulttuurin majakkana', In Maailman hauskin kuvasarjalehti. Aku Ankka -lehti 50 vuotta, edited by J. Tolvanen (Helsinki: Helsinki Media), 84.

${ }^{72}$ Kantola, Anu: ’Ikuisen odotuksen paikka - Aku Ankka modernin ihmisen yhteiskuntana.” Maailman hauskin kuvasarjalehti. Aku Ankka lehti 50-vuotta. Toim. Juhani Tolvanen. Helsinki Media, Helsinki 2001, 151.

${ }^{73}$ Svetlana Boym, The future of nostalgia (New York: Basic Books, 2001), xvi. 